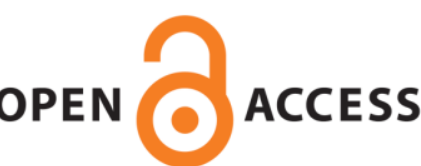

OPEN ACCESS

UWS Academic Portal

\title{
Policy in transition
}

Gillies, Donald; Mifsud, Denise

Published in:

Journal of Education Policy

DOI:

10.1080/02680939.2016.1196393

Published: 30/11/2016

Document Version

Peer reviewed version

Link to publication on the UWS Academic Portal

Citation for published version (APA):

Gillies, D., \& Mifsud, D. (2016). Policy in transition: the emergence of tackling early school leaving (ESL) as EU policy priority. Journal of Education Policy, 31(6), 819-832. https://doi.org/10.1080/02680939.2016.1196393

\section{General rights}

Copyright and moral rights for the publications made accessible in the UWS Academic Portal are retained by the authors and/or other copyright owners and it is a condition of accessing publications that users recognise and abide by the legal requirements associated with these rights.

\section{Take down policy}

If you believe that this document breaches copyright please contact pure@uws.ac.uk providing details, and we will remove access to the work immediately and investigate your claim. 
Policy in transition: the emergence of tackling early school leaving (ESL) as EU policy priority

This paper explores, from a Foucauldian perspective, the emergence and nature of the current EU education policy priority issue of 'early school leaving'. The paper suggests that a number of problematizations developing from the failure to secure Lisbon Strategy objectives have served to create a much stronger focus on the issue of young people deemed to be leaving education and training early in EU states. In examining how EU policy discourse positions such young people (subjectivation), the paper highlights how this has narrowed to a concern with young people as economic problems and principally positioned as economic units which require to be more productive. Education and training are understood as investments in human capital and as the principal means to secure the dominant global economic position desired by the EU. The paper suggests, however, that human capital theory has been modified within this approach so that merely being retained in an educational setting is seen as proxy for the investment which education and training represent. This is a weaker policy position than previously espoused but, born of economic crisis, one which addresses related EU political aims of softening youth unemployment figures, dampening associated unrest, and reducing risks to social cohesion.

Keywords; discourse; analysis

\section{Background}

This paper analyses the nature and development of a current EU education policy priority tackling early leaving from education and training (ELET, but now known as 'early leaving from school': ESL). Countries within the EU committed themselves in 2009, through the Strategic Framework for European Cooperation in education and training ('ET 2020'), to reducing the proportion of early leavers from education to less than $10 \%$ by 2020 . In 2010 , a research report on the issues was commissioned (Dale, 2010) and in 2011, education ministers agreed on a 'framework for coherent, comprehensive, and evidence-based 
policies' to tackle early leaving. The Council of the European Union issued some policy guidelines for member states in 2011, and the European Commission submitted a detailed report on the issue in relation to the Europe 2020 Agenda, with an accompanying staff working document. From 2011, a working group bringing together policy makers and practitioners from across Europe looked at examples of 'good practice' and promoted an exchange of experiences on this issue, most notably a Flanders case study (European Commission, 2014a). The European Commission published the working group's final report in 2013 (European Commission, 2013). This notion of 'good practice sharing' is problematized by Souto-Otero et al. $(2008,245)$, who describe this as the 'lemming effect' whereby 'supposedly best practice which has been wrongly declared' is implemented by countries who subsequently end up on the road to regression, rather than progression. This demonstrates the adverse effect that open methods of co-ordination (OMC), in terms of policy change induction, can have on the problem-solving capacity of politics.

In 2014, a whole raft of publications was released in relation to the ET 2020 working group on school policy, one priority area of which is teacher education and the other, ESL. On ESL, developments were: a Eurydice/Cedefop joint report on comprehensive policies against ESL (European Commission, 2014b); a Commission study on the effective use of early childhood education and care (ECEC) in preventing early school leaving (European Union, 2014) ;The European Lifelong Guidance Policy Network (ELGPN) published a concept note on the role of guidance to prevent ESL (Oomen and Plant, 2014); the European policy network on the education of children and young people with a migrant background (SIRIUS) published a policy note on ESL and pupils with a migrant background (Nouwen et al., 2015) ; and, NESET country reports on equity in education for all 28 member states were promised (see also Schraad-Tischler and Kroll, 2014) .

Finally, in the context of the European Semester 2015, country-specific recommendations have been issued to some Member States focusing on reducing early school leaving as a policy priority area. Concern was raised at the lack of progress towards early school leaving reduction in such countries as Bulgaria, Cyprus, Spain, Hungary and Italy. 
The definition of 'early school leaving' used at EU level refers to 'those young people who leave education and training with only lower secondary education or less, and who are no longer in education and training'. In statistical terms, European ESL rates are measured as the percentage of $18-24$ year olds in such a position. In 2012, figures estimated some $12.7 \%$ of the relevant population counted as early leavers, totalling some 5.5 million European citizens (European Commission, 2013, 8). Policy strategies were categorised under three broad headings: prevention; intervention; and compensation. These covered various aspects of educational provision such as the preventative high quality early childhood education and care; the intervention of early warning systems and support frameworks in schools; and compensatory action such as 'second chance education' (18-24).

There is a considerable body of literature on the issue of early school leaving, but as this focus is on EU policy discourse, the substantive issues emerging from the research literature will not be considered in detail at this point. However, the notion of early school leaving in European policy has been problematized in research literature. Reducing early school leaving as the key contribution that education can make to address the economic crisis identified by the EU, the Commission and various national governments assume the presence of a directly causal relationship between the alarming levels of youth unemployment and early school leaving (Ross and Leathwood, 2013a). The objectification of the early school leaver as being the cause of the problem is challenged by Downes (2013), who argues that it is more the student's lack of voice in the whole matter that leads to alienation from the educational system. On the other hand, one must also keep in mind the presence of strong socio-economic factors that lead to the predisposition of early school leaving among certain vulnerable groups (Vajello and Dooly, 2013). De Witte et al. (2013) adopt a rational cost-benefit calculus framework in order to dismantle the traditional belief of early school leaving regarded as 'irrational behaviour of young people' (340), in turn identifying various system characteristics of economies, labour markets and education systems in EU countries that act as drivers in the young people's decision to drop out. Ross and Leathwood (2013b) further argue that the concept of ESL captures a simplistic generalisation masking both the nature of educational trajectories, as well as the relationship between education and the labour market. They question the emphasis that the European Commission makes on the urgency of delivering the right skills for 
employment', stating that lack of skills is certainly not the root of the economic crisis, as indicated by the high level of unemployment among European graduates. They further problematize the notion of 'skills' and 'employability' as presented by the European Commission, alluding to the presence of the "'blame the victims" mentality' (406), the whole concept reflecting 'not only a narrow conceptualisation of education, but also of the needs of labour market and of the strengths and potential of young people' (ibid). In other words,

'Early School Leaving' is a concept that is problematic, not merely because it is imprecise, and masks a variety of potentially indirect routes to the successful completion of an education, and not simply because it is being used as a political panacea to address youth unemployment ... more significant[ly] ... it becomes a marker for social exclusion, a means of maintaining inequities in societies.

(Ross and Leathwood, 2013b, 415)

This European policy trajectory can be compared with the new school-leaving age policy in New South Wales, Australia, introduced without any consideration of its impact in complex contexts of gender, ethnicity and ability (Reid and Young, 2012). The latter borrow from Billett et al. (2010) in their suggestion that such a policy is nested within a neoliberal framework which emphasises individual responsibility in education-work transitions, thus doing away with government aid. All this is justified through the proliferation of globalisation - 'as both ideology and justification that it is widely considered simultaneously necessary and inevitable' (Reid and Young, 2012, 798). Situated within the same Australian context, Hodgson (2011) also positions the school-leaving age policy within the broader field of neoliberal reform, drawing on Foucault's notion of governmentality to argue that the primary concern with students who are classified at 'educational risk' is a very narrow framework, excluding other forms of addressing the situation as 'unthinkable and unsayable' (128).

\section{Research questions}

The research is founded on Foucauldian theory and explores the emergence, through problematization, of the policy priority (genealogy); the ways in which the subjects of the policy initiative are positioned (subjectivation); and, the governmental rationality which 
underpins the policy (governmentality). The study analyses how the policy development represents both continuity and disruption in relation to current trends in European and global educational governance.

The study, therefore, examines three main research questions:

1. From where, and within which policy context, does this priority emerge, and why?

2. How does it position/subjectify the young people who are the focus of the policy initiative?

3. What rationality underpins and drives the policy detail?

From the perspective of a Foucauldian theoretical framework, the analysis aims to trouble the discourse by probing the inherent assumptions, the contingency of the discursive construction of both problem and solution, and the coherence of, and normative assumptions manifest in, the rationale on which this policy is founded.

\section{Methods}

This study is positioned within the broad framework of Foucauldian discourse analysis and uses selected EU policy texts ('serious statements') as the focus of its analysis. In a rare and explicit reference to discourse analysis, Foucault recognises that one approach is to treat discourse as a set of linguistic facts linked together by syntactic rules of construction' (2002a, 2). However, his focus is not on this 'linguistic dimension' but, instead, on discourse as 'a set of polemical and strategic facts' and so his analysis is of 'discourse as a strategic and polemical game' $(2002 a, 3)$. This is a helpful distinction and one which explains why the way in which Foucault engages in what we now would recognise as 'critical discourse analysis' often is not rooted in close analysis of specific words, phrases and concepts, but rather deals with the play of ideas, the power games employed through discursive practice.

As Foucault indicated, his analysis is not directed at the micro, linguistic level and so applying his theory to policy documents requires allying this with more granular approaches. Even within the Foucauldian tradition, there is a wide range of approaches to this more linguistic form of discourse analysis, and this study follows the approach developed by Jäger and Maier (2009). In keeping with the 'critical' tradition, Jäger and Maier understand 
discourse as constituting an exercise in power, and critical discourse analysis not only as aiming to reveal contradictions, assumptions, and immanent problems within the discursive texts under scrutiny but also to undertake the analysis from a position committed to social equality and justice (van Dijk, 2009, 63). The 'critical' element, therefore, refers not just to Foucault's project to question, probe, and challenge but to the Critical Theory tradition which positions this form of research as a potentially 'emancipatory' exercise in challenging dominant power structures, and tackling issues of injustice, inequality, and oppression.

In Jäger and Maier's terms the EU policy text under scrutiny may be labelled a 'discourse fragment', although within it there may be other fragments too which relate to different discourse strands $(2009,46-47)$. In addition, the context of EU policy may be considered as a discourse plane - 'a social location from which speaking takes place' (48). Of more immediate importance are the tools which Jäger and Maier $(2009,55)$ provide as a means for undertaking discourse analysis, summarised as: context; surface of the text; rhetorical means; content and ideological statements; other peculiarities; discourse position (ideological stance) of the text. These headings provide a comprehensive procedure to aim to achieve the ends of critical discourse analysis.

\section{Genealogy}

While many see Foucault's two principal methods - archaeology and genealogy - as overlapping and not easily or usefully distinguished, genealogy can be seen to focus more on historical trajectory than contemporaneous practice, which is more the domain of archaeology. Archaeology explores the nature of a discursive system, uncovering its rules of formation within a specific historical context. Genealogy, on the other hand, is more concerned with the descent and emergence of discourse, with a focus on disruptions and sudden jolts rather than on providing a seamless historical narrative with its totalizing abstraction and explanatory closure. Genealogy has more of a focus on history, on power relations, on trajectories, however erratic their course, than on archaeology's analysis of discursive formations at a given point. Genealogy seeks to probe the sets of relations and developments that enable different forms of knowledge to emerge (Olssen, 2006, 18), the 'haphazard conflicts' and the 'randomness of events' (Foucault, 1984, 88) which are integral to the process of discursive change. 
This method, therefore, seems eminently suited to this paper where the emergence of the EU concern with the school leaver is being probed as a policy priority. The study aims to investigate how this policy priority can be seen to have emerged from the broad horizon of European policy interests, and to identify the problematizations which have led to the construction of the school leaver as a policy problem, an issue for which a solution is deemed necessary (Foucault, 2000a, 118). Of course, one must also question the extent to which 'a "policy solution" can be considered problem-solving' (Souto-Otero et al., 2008, 245) due to the economic, technical, geographic, historical and cultural factors impinging on the context-specific nature of policy transfer.

\section{Subjectivation}

The construction of the school leaver as a policy target is also a focus of this research study. How individuals become subjects within regimes of truth was a key interest of Foucault but much of his later work was concerned with care of the self, rapport á soi, and technologies of the self (Foucault, 2000b, 2000c, 2000d). Here his interest was in how people made themselves subject, formed themselves within discursive regimes. In this paper, however, the focus is on how the policy initiative under scrutiny positions the subjects of its interest school leavers. This may seem to take us back to the earlier Foucault and his notion of 'docile bodies', and normalisation (1991a) but the discourse also gives young people agency, especially in terms of responsibilisation. A 'docile body' would lack the capacity for selfformation to which they are interpellated here, and so the analysis must be of the ways in which young people are not only positioned but called upon to position themselves.

In exploring the way in which the school leaver is positioned within the ESL policy discourse, further theoretical weapons will be used. The work of Walter Benjamin (1916) on language pre-dates the linguistic turn of the $20^{\text {th }}$ century and the emergence of discourse as a key research interest, but his understanding of 'being' in language is an interesting one. Benjamin suggests that what is communicated in language is 'being' and so by exploring the ESL discourse one can begin to sketch out as what sort of 'being' the school leaver is presented. In a sense, one could call this a 'personal imaginary' - the sort of policy subject the school leaver is deemed to be. A further useful insight into this issue is the work of 
Bansel (2014) on the 'subject of policy'. Bansel's work challenges the way in policy tends to view the subject by developing a much fuller, more nuanced picture of the subject of policy $\therefore$. as materialised from constitutive relationships between: the multiple and the singular; the body politic and embodied subject; the human and the non-human' (3). Bansel challenges the assumptions made by policy discourse about the subject and resists the 'numerical reductionism' (6) evident in neoliberal policy discourse where the subject of policy becomes a simplified, quantifiable object. Bansel's work provides a useful means to interrogate EU policy texts for how the school leaver is depicted within the policy narrative.

\section{Governmentality}

Foucault's well-known concept of governmentality was developed as a means of exploring the rationality underlying state government (Foucault, 2002b). In a series of studies, Foucault explores different manifestations of this within different historical periods, culminating in his Collège de France lectures on neoliberal governmentality (Foucault, 2008). Governmentality research aims to unpick the rationale which underpins the ways in which government operates and this is a valuable tool when exploring the thinking, the reasoning, upon which the ESL policy development is founded. Although much of Foucault's work on governmentality was conducted at the macro level of the state, he also understands governmentality to operate at the personal level - the ways in which individual humans control themselves, direct their own behaviour, and the rationality, the purposiveness which they employ to govern it (Foucault, 2000c). It is eminently plausible therefore to deploy a governmentality approach to dealing with EU policy, even a single instance of it. This should not be undertaken as a discrete, compartmentalised activity because it is clear that the governmental rationality foundational to ESL policy discourse will also influence the understanding of the subject of policy. The rationality which legitimises the policy initiative and policy purpose will at the same time, of necessity, influence the discursive construction of the object of that policy, the school leaver. Indeed, the rationality operating at these levels will also be evident in the very problematization of policy, the identification of the policy problem, and so one must see elements of governmentality cutting across all three research questions: the emergence of the policy; the subject of the policy; the underpinning rationality. 


\section{A geneaology of Early School Leaving as an EU policy priority}

Foucault (2000a) explains how policy solutions can be seen as a response to 'a specific form of problematization' (119) and he contemplates the possibility of developing a history of problematics as a way of capturing this development in human society, how 'a domain of action' enters the field of thought because of the identification of contextual difficulties. In other words, difficulties in a set of actions can give rise to a number of possible responses. One can see, therefore, that a genealogical approach can be used to identify those moments where problematization was voiced or became discursively recognisable, whereas a governmentality approach can help outline the basis on which the chosen action was founded - the rationality underpinning the selected 'solution'.

It is possible, but not exhaustively so, to identify the Lisbon Strategy of 2000 as marking the emergence of a significant problematization within EU politics. Lawn and Grek $(2012,83)$ identify this moment as 'a key culminating point in the history of educational governance in the EU', where education as a focus of attention moves from the shadowy sidelines to a central economic role, where 'learning' and the 'knowledge society' become dominant discourses (85-6). This Europeanization of policy in all domains, including education, can be regarded 'as part of the new scalar politics, articulating with and responding to globalization' (Grek et al., 2009, 124). This leads to the 'economization of education policy' argument, which according to Grek et al. (2009), is a 'human capital framing of education policy which has challenged the subsidiarity argument about the place of education within Europe' (126), through which national autonomy and policy-making have been transformed by globalized discourses and Europeanization processes. Pépin (2011), however, cautions against seeing the Lisbon Strategy as representing a 'rupture' in European policy trajectory but rather as a culmination of growing developments within the EU. It could be argued that this move traversed a terrain within which educational and economic interests were seen first to be aligned, then to overlap, and finally to become fused. Jones (2005) similarly views the Lisbon Strategy as being part of a development stemming, most immediately, from Jacques Delors' White Paper of 1993, Growth, Competitiveness, Employment (European Communities- Commission, 1993), which had argued, amongst other things, that demographics suggested that within Europe there would be future difficulty in meeting public commitments, particularly in relation to an ageing population and a concomitant 
declining youth cohort. It argued that economic returns from EU workers had to be optimised and so was promoted the importance of education and training. Ertl (2006), however, shows the problematization giving rise to the Lisbon Strategy had shifted somewhat by 2000 . Ertl $(2006,15)$ points out that there was a heightened economic concern which made much more of the effects of globalization as an economic driver: '... increased competition in globalized markets, the challenges posed by the knowledge-driven economy by the EU's main competitors (the USA and Japan) and by the advent of China as the leading manufacturing nation...'

In exploring this history of ESL problematics, some recognition of the overall nature of EU education policymaking is advisable. As has been noted, EU policy on state education, and certainly prior to the Lisbon Strategy, has been categorised as 'weak', in its deference to national sensitivities and so its early inability to promote commonality or coherence (Lawn \& Grek, 2012, 35). Souto-Otero et al. (2008) propose a four-stage classification outlining the trajectory of EU policy-making in education for the last five decades, identified by the usage of policy-making tools by the Commission. The first period (1957-1974) can be characterized by the proclamation of the right for Europe to establish itself as a political community, with recognized efforts being made by the Heads of Government in order to co-operate in the field of education (Janne, 1973). While Janne's report did call for some harmonization in the field of education, he did also stress that national structures and traditions in education be respected 'scrupulously' in any such development (p.51). The second period (1975-1992) was distinguished by legal regulation and policy-making through the setting up of Community action programmes (such as PETRA, ERASMUS, COMETT and LEONARDO). These targeted programmes, which unfolded against the background of poor economic performance and high unemployment levels in the majority of EU countries, focused on schools: mobilisation for integration; promotion of equal opportunities and increased mobility between Member States; vocational training to support transition to working life and reduction in youth unemployment; and the quest for a pan-European labour market. Consequently, Souto-Otero et al. (2008: 236), drawing on Ertl (2003), argue that these EU action programmes 'have been the main approach of European Commission to initiate cooperation between the EU countries for the last three decades ... result[ing] in a certain convergence of Member States' educational policies; they will also continue to cause stakeholders in Member States to pursue similar ways of reacting when faced with new problems'. The third period (1993-2000) was characterised by the issuing of a large number of reports and memoranda that focused on 'transparency' and finding common benchmarks for qualification progression and validation among the various countries, which would pave the way for the OMC ('open method of co-ordination'). The fourth phase (2000 onwards) gives rise to the OMC 'as a mechanism for policy-making based on the use of benchmarks, 
indicators, exchange of good practice and peer review which carries no sanctions on noncompliance, but seeks impact on national governments from the pressure of having to justify one's action in the light of a common evaluation of its compliance with joint goals' (Souto-Otero et al., 2008: 237, emphasis added). It is here that one can detect the presence of neoliberal governmentality through more subtle control mechanisms, with OMC used to steer at a distance.

According to Hingel (2001), the Lisbon conclusions represent a shift from the historical convention of stressing the diversity of European education systems by asking the Ministers to prioritise instead common denominators, while respecting these differences. This was the starting point for the EU to initiate a draft of possible general objectives of education systems based on national contributions in Europe: augmenting the quality and effectiveness of education and training systems in the EU; ensuring access to these systems; and making them visible to the world at large. Notwithstanding the intrinsic involvement of the EU in education policymaking for over half a century, and its particular focus on vocational training, the repeated failures of EU education policy to achieve its own targets suggests that the OMC approach and its associated mechanisms, from the perspective of those seeking greater European union is concerned, merely continue the weak tradition of EU policymaking in the education sphere.

The Lisbon Strategy set out a goal for the EU to 'to become the most competitive and dynamic knowledge-based economy in the world, capable of sustainable economic growth with more and better jobs and greater social cohesion' (European Parliament, 2000). There are twin tasks, therefore for the EU world of education and training: firstly, that a 'knowledge' economy creates certain expectations of the education systems in terms of the capacities and capabilities of its products (young people), and, related, the recognition of the rise in economies such as China and India in terms of manufacturing, especially in cheap exports, means that the 'better jobs' required by the EU will demand a higher-qualified workforce. These are connected but not quite the same.

The result, therefore, was a much greater economic emphasis on education and training across the EU. By 2004, further problematization became evident (Lawn and Grek, 2012, 91). The Lisbon goals were not being met, the huge expansion of the EU meant even more challenges in relation to young people's educational outcomes, and there was the continued rise of competitor Chinese, East Asian, and Indian economies. By 2008, the financial crisis has created further problems for the EU strategy (European Commission, 2010) and it is 
now that we see even more specific focus on young people and the emergence of the ESL policy alongside ET 2020. What has emerged as a problematic area is not just the quality of the EU workforce and the skills and capacity of its young, but the emergence of youth unemployment and social cohesion as policy concerns. Thus ESL with its focus on young people and staying on in education and training is not simply an economic policy but also one related to social concerns, the potential for unrest and alienation, and the added social costs which unemployment creates. In ESL, while the concern for economic output remains high, what has altered is the increased need for education and training as a form of discipline, a form of containment.

[Table 1 around here]

What is common throughout this short history of problematics is the economic constant. Some of the discourse has softened (in terms of the crude goal of economic growth, there is more reference to growth coupled with social benefits - ('Smart, Sustainable and Inclusive Growth') and policies aimed at "growth-friendly impact" rather than growth per se (Schraad-Tischler and Kroll, 2014, p.15). Nevertheless, the series of actions in relation to ESL can be seen as rooted in economic concerns: the perceived need for the EU to achieve economic growth targets; actions in response to the failure to achieve EU economic targets; and actions in response to social consequences of global economic volatility. According to Grek et al. (2009), this constitutes a 'polymorphic landscape' (121) where education is used to craft a culture of 'numbers and comparison, where Europe is newly reconfigured as a single, commensurable space' (122). They confirm this shift in culture as one of the central constituents of the novel European knowledge economy. In the words of Ball (2015), this is an indication of 'how numbers bite deep into practice, into subjectivity and how they do the work of governing us better' (300).

\section{Subjectivation}

While a geneaology of the subject of EU policy in relation to education and training could be productive, in this instance the focus is very much on recent policy papers and the way in which young people, as targets of policy, are positioned. The two key policy papers in question are Council of the European Union (2009 and 2012). 
The 2009 document frames its concern with reference to the European 'ambition to become the most competitive and dynamic knowledge-based economy in the world' (119/2). It then refers to 'education and training' having a 'crucial role to play in meeting the many socioeconomic, demographic, environmental and technological challenges facing Europe and its citizens...' (119/2). An 'essential component' of the overarching economic strategy is 'efficient investment in human capital through education and training systems' (119/2). The Europe 2020 Strategy sets the 'discursive field' (Foucault, 1991b, 161) for the failure of the Lisbon Strategy objective to be fulfilled in terms of EU dominance in the global economic market - the focus on ESL as the 'regime of truth' (Foucault, 2002c) which conditions the prominence given to education and training, not per se, for the essential human good, but for the economic gains of the State (that is, the EU), in order to be utilized as a vehicle for EU-driven reform. This enables an understanding of how the subject is produced 'as an effect' through and within discourse and within specific discursive formations. Thus a 'regime of truth' is constructed by EU policy in its identification of ESL as a priority area, early school leavers are interpellated to subjectify themselves to this, and, moreover, individual governments of the member states are made subjects themselves by the EU targets, country-specific recommendations, and comparative data pressures.

The document, therefore, represents young people as 'human capital', investment in which will secure the economic desires of the European Union. Nevertheless, while this economist, instrumental approach is foregrounded, it is also matched by what may be seen as more humanist, progressive discourse when the document states that in addition to this economic purpose, 'investment in human capital' will also be about 'promoting personal fulfilment, social cohesion and active citizenship'. This is all covered in one lengthy but unified sentence and therefore one has to recognise that a degree of intertextuality is at work here: on the one hand neoliberal, economist discourse and on the other discourse more akin to social democratic ideals. One could see this as typical of much EU discourse which needs to appeal to many different constituencies from the more neoliberal and economic rationalist viewpoints to the more democratic ideals of others. One can detect a discursive struggle between neoliberal economy and social democracy, presenting itself as 'a battle among discourses and through discourses' (Foucault, 1975a, x), through the EU 
education policy discourse. Thus, concern with early leaving from education is presented on the one hand as economic waste but on the other hand, in France for example, as an issue of equity and social justice. While the document insists that education and training be seen as 'firmly anchored' (119/2) in the broader strategy about economic growth and employment, the primary goals for education and training systems in the period up to 2020 are said to be 'aimed at ensuring:

(a) the personal, social and professional fulfilment of all citizens;

(b) sustainable economic prosperity and employability, whilst promoting democratic values, social cohesion, active citizenship, and intercultural dialogue' (119/3)

This fusing of personal, social, fundamentally humanist goals and those of economic demands continues throughout the document so that, for example, we read: 'As well as engendering personal fulfilment, creativity constitutes a prime source of innovation, which in turn is acknowledged as one of the key drivers of sustainable economic development' (119/4). In a sense, that sentence could be seen as typical of the intertextual tightrope which is traversed in the policy: the fundamental drive is for economic growth but at the same time there is recognition of more human, personal goals. In Foucauldian terms, this can be explained as a discreet interplay between 'political rationality' and 'technology of government' (Olssen, 2003, 197), where the discourse of humanism is utilized as a mask to ease in the economic agenda - thus the exercise of EU governmentality.

In seeking to establish benchmarks for member states, the document suggests data on the following aspects be gathered: adult participation in lifelong learning; low achievers in basic skills, tertiary level attainment; early leavers from education and training; early childhood education (119/7). The member states thus become akin to the 'docile bodies' (Foucault, 1991a, 138) of EU policy, with the disciplinary practices resulting from 'a multiplicity of often minor processes, with discipline being 'a political anatomy of detail' (138-9). EU policy exercises discipline on the member states through their own 'self-regulation'. With specific reference to early leaving from education and training, member states are invited to prioritise the following: 'strengthen preventive approaches, build closer cooperation between general and vocational education sectors and remove barriers for drop-outs to return to education and training' (119/10). Lange and Alexiadou (2010) draw attention to 
the fact that policy solutions based on benchmarks, indicators and targets portray this as a 'neutral activity that is based on objective knowledge' (454) from statistics collected from all member states, in disregard of the actual meaning of these figures for both the individuals and their societies. This is illustrated by a comparison of the social stigma associated with early school leaving in Northern European societies and the weaker effect it would have in some Mediterranean countries.

The document of 2012 has an air of urgency for the EU, in the context of 'the worst financial and economic crisis in its history' (70/9). The economic focus is much more stark: 'education and training systems have to be modernised to reinforce their efficiency and quality and to equip young people with the skills and competences they need to succeed on the labour market. This will boost people's confidence to be able to stand up to current and future challenges'. This is an interesting development in the discourse: broader goals of personal fulfilment are omitted, there is a stronger economic focus, and young people are responsibilized to face economic crises with 'confidence'. This can be regarded as a 'technology of the self' (Foucault, 2000d) whereby the subjects of policy are called upon to perform acts of compliance or resistance in relation to the economic discourse through resuming their educational training or getting a job. Investment in education (70/10) aims at combining 'efficiency and effectiveness with growth-friendly impact'. This document makes no reference to the personal fulfilment of the earlier one and it can be seen to represent a much starker, economic-focused discourse. Across the two documents emerges a struggle between discourses, whereby the economic discourse comes to attain a dominant position over the social democratic discourse.

In seeking to summarise the subjectivation of young people and, in particular, the early leaver from education or training, in these documents, one could say that the earlier document presents young persons with personal, social, and economic needs and desires while the latter document has a much more functional tone with young people as representing an economic problem requiring an economic solution. It could be summarised as meaning that the economic crisis has produced a much more narrow concern with economic recovery rather than on the development of citizens. The 2009 and 2012 policy constructions are regarded as 'a space of differentiated subject-positions and subject- 
functions' (Foucault, 1991b, 58). The early school leaver is thus 'fabricated' into the social order, becoming an effect through and within discourse (Foucault, 1991a, 217).

\section{Governmentality}

In relation to its focus on early leavers from education and training, the rationale driving policy can been to be very much driven by the discourse of Human Capital Theory, rooted in economic rationalism. The early work of Schultz $(1960,1961,1962)$ was an attempt to explain the differential wages of college and non-college graduates; the later work of Becker $(1962,1972,1975,1992,2002)$ developed this into viewing education and training (investment in human capital) as causal factors for economic improvement at both the micro (individual) and macro (state) levels. It should be noted that this focus on human capital theory is not new here and can be seen strongly, for example, in earlier EU policy on 'efficiency and equity in European education and training systems' (Commission of the European Communities, 2006). This document, for example, views educational inequities as evidence of 'waste' and purely from the perspective of added economic 'costs', rather than in any social or moral terms. However, what the EU strategy on early leaving from education and training seems to have done, is to see staying on at school or college as a proxy for 'investment'. This is a subtle but significant shift in human capital theorizing but it also serves a blunter political goal. Young people staying on at school do not therefore contribute to worrying figures of youth unemployment or to the related data gathered on those not in employment, education or training. The technique of what Foucault (1991a) terms as 'normalizing judgement' (p. 183) aims at EU conformity in defining early school leavers at education policy level. This leads to the 'lowering of threshold of describable individuality' (Foucault, 1975b, 191) as all European 'early school leavers' (as labelled by the EU policy), are categorized in a homogeneous manner without taking the socio-economic factors into consideration. The self-formation of early school leavers as 'students' (mature, at this stage) is a form of normalization, utilized as a political rationality that attempts to set the discursive field for the hegemony of economic governmentality. The 2012 policy document also refers to the quality of teaching for the first time, stressing its role in tackling early school leaving and the acquirement of basic skills (70/17). The drive to increase tertiary attainment levels can be seen as drawing on classic human capital rationality, but 
merely retaining young people in school can be seen as more indirect, a modification of the theory.

In addition to the Human Capital Theory influence, the rationale underpinning the EU approach in the area of education is influenced by further thinking around governmental practice. The first is the strategy of the open method of co-ordination where there is due respect for national sovereignty and political difference so that policy is developed through working groups largely, drawn from disparate constituencies. One could see this as linked to the Foucauldian view of liberalism as 'not wanting to govern too much' (Foucault, 2000e). However, allied to that is the drive to effect a common strategy towards shared goals and that is achieved through aspects of steering and nudging: common benchmarks, data and statistical comparison, and country-specific recommendations (Lawn and Grek, 2012, 57). Accountability in education, which is defined as technical accountability through international and national comparative measures of performance, has displaced political accountability, while performativity contributes to burgeoning problems of diminished trust across and within education systems. This has been generated due to the emphasis on knowledge production to demonstrate performance in quantitative forms that can be divulged, evaluated and converted into standards and indicators (Ozga, 2013). The 'Open Method of Co-ordination' 'offer[s] a new space for the manifestation of differential power relations between the Commission and the member states, as well as between different member states' (Lange and Alexiadou, 2010, 445). Concepts of indicators, benchmarking and quality assurance have become the new dominant discourses in the process of fabricating the space of European education' (Grek et al., 2009, 127).

The overall rationality of rule in place, therefore, is something of a typical EU balance: there is the economic rationalism which places education in a supportive role to economic aims; the modified Human Capital Theory which sees retention with educational establishments as a sufficient minimum goal; the liberal preference for limited direction; and the neoliberal, or advanced liberal, preference for steering rather than direct control.

\section{Conclusions}


Policies designed by the EU to encourage member states to tackle the issues of high rates of youngsters leaving early from education and training can be seen to be directly linked to the overall strategy developed since Lisbon 2000 of promoting the EU as the dominant global economic bloc. More recent developments have been prompted by the failure to achieve earlier goals and the problems arising from the economic crisis dating from 2008. Both the economic situation and the position of young people have been problematized, requiring solutions. As the economic crisis has continued, EU discourse sees young people as a problem and a risk specifically as economically unproductive capital. From an earlier concern with the whole person, the discourse has narrowed to viewing young people as economic units which require to be more productive, as problems which need to be solved. They are also, to a limited extent, seen as responsible in relation to requiring the skills and competences to 'succeed' and the 'confidence' to withstand economic challenges.

The policy discourse remains wedded to economic rationalism and Human Capital Theory. The overall goal remains economic growth, and education and training are expressly harnessed for these very same aims. They are viewed as an 'investment' which aims to 'combine efficiency and effectiveness with growth-friendly impact' (Council of the European Union, 2012, 70/10).

Where the governmentality of this approach has shifted is that while Human Capital Theory focuses on education and training as the key driver of economic success and growth, mere presence in an educational establishment is viewed as sufficient within the current economic climate. Preventing early leaving from education and training is taken as a proxy for investment in education but it is somewhat removed from the actuality of educational provision. It seems a somewhat attenuated version of Human Capital Theory. However, as has been indicated, it does, within the terms of an economic crisis, prevent youth unemployment figures from becoming further bloated, with consequent risks of unrest and threats to social cohesion. It also remains attached, albeit weakly, to notions of equity and social justice and the unequal socioeconomic prospects for those who achieve educationally and those who do not. 
The policy discourse reflects the double-coding typical of the EU, with the attempt to appeal to different political and theoretical viewpoints. At the same time, it is wedded explicitly to education as instrumental to the knowledge economy and to economic growth as the ultimate goal. As Amartya Sen (2011) has questioned, however, there is a silence about what economic growth is for, and for whose benefit it is generated.

The policy is shaped, as would be expected, by a neoliberal focus on the individual and individual responsibility for economic worth. Young people are positioned as requiring to be skilled, mobile, self-reliant, economic agents and notions of their 'potential' and 'fulfilment' are centred on their economic value. Moral and social concerns are re-shaped as economic calculations so that issues such as inequality, discrimination, and disadvantage are seen primarily as indicators of 'economic waste', while creativity, travel, language skills are valued primarily for their potential to increase economic returns.

One can therefore see this as a policy in transition in more than one way: it deals with the transition from education and training to the world of employment, the transition from the school to the workplace, from the status of student or pupil to that of employee or worker; in its own terms, however, it is also a policy in transition, a policy shifted by the winds of global economic change, the effects and consequences such blasts can bring, and the problematics and related policy adjustments which follow. 


\section{References}

Ball, S.J. 2015. "Education, Governance and the Tyranny of Numbers." Journal of Education Policy 30 (3): 299-301. doi: 10.1080/02680939.2015.1013271

Bansel, P. 2014. "The Subject of Policy." Critical Studies in Education 56 (1): 5-20. doi: $10.1080 / 17508487.2015 .971839$

Becker, G. 1962. "Investment in Human Capital: a Theoretical Analysis." The Journal of Political Economy 70 (5): 9-49.

Becker, G. 1972. "Schooling and Inequality from Generation to Generation Inequality: Comment." The Journal of Political Economy 80 (3): S252-S255.

Becker, G. 1975. Human Capital: a Theoretical and Empirical Analysis. 2nd ed. New York: Columbia University Press.

Becker, G. 1992. "Human Capital and the Economy." Proceedings of the American Philosophical Society 136 (1): 85-92.

Becker, G. 2002. "The Age of Human Capital." In Education in the $21^{\text {st }}$ century, edited by E. Lazear, 3-8. Stanford CA: Hoover Institution Press.

Benjamin, W. (1916) 2007. "On language as such and on the language of man." In Reflections, translated by Edmund Jephcott, 314-332. New York: Schocken Books.

Commission of the European Communities, 2006. Efficiency and equity in European education and training programmes. Brussels.

Council of the European Union. 2009. Council Conclusions of 12 May 2009 on a Strategic Framework for European Cooperation in Education and Training ('ET 2020') (2009/C 119/02).

http://eur-lex.europa.eu/LexUriServ/LexUriServ.do?uri=OJ:C:2009:119:0002:0010:en:PDF Council of the European Union. 2012. 2012 Joint Report of the Council and the Commission on the Implementation of the Strategic Framework for European Cooperation in Education and Training (ET 2020) (2012/C 70/05).

http://eur-lex.europa.eu/legalcontent/EN/TXT/PDF/?uri=CELEX:52012XG0308(01)\&from=EN

Dale, R. 2010. Early School Leaving. Lessons from Research for Policy Makers. Brussels:

European Commission. http://www.nesetweb.eu/sites/default/files/early-schoolleaving-report.pdf 
De Witte, K., Nicaise, I., Lavrijsen, J., Van Landeghem, G., Lamote, C. and Van Damme, J. 2013. "The Impact of Institutional Context, Education and Labour Market Policies on Early School Leaving: a comparative analysis of EU countries." European Journal of Education 48 (3): 331-345.

Downes, P. 2013. "Developing a Framework and Agenda for Students' Voices in the School System across Europe: from Diametric to Concentric Relational Spaces for Early School Leaving Prevention." European Journal of Education 48 (3): 346-362.

Ertl, H. 2003. "EU programmes in education and training: development and implementation in Germany, Sweden and the United Kingdom". In: Implementing European Union education and training policy. A comparative study of issues in four Member States, edited by D. Phillips and H. Ertl, 161-188. Dordrecht: Kluwer.

Ertl, H. 2006. "European Union policies in education and training: the Lisbon agenda as a turning point?" Comparative Education 42 (1): 5-27

European Commission. 2010. Lisbon Strategy evaluation document (SEC(2010)114 Final). Brussels: the European Commission.

European Commission. 2013. Reducing Early School Leaving: Key Messages and Policy Support. Final Report of the Thematic Working Group on Early School Leaving. Brussels: The European Commission.

European Commission. 2014a. Report on the Case study on Antwerp, Belgium-Flanders, June 2014 Working Group on School Policy - Early School Leaving . http://ec.europa.eu/education/policy/strategic-framework/expertgroups/documents/report-belgium-study en.pdf

European Commission/EACEA/Eurydice/Cedefop. 2014b. Tackling Early Leaving from Education and Training in Europe: Strategies, Policies and Measures. Eurydice and Cedefop Report. Luxembourg: Publications Office of the European Union.

European Communities - Commission. 1993. Growth, competitivesness, employment - the challenges and ways forward into the $21^{\text {st }}$ Century (White Paper). Luxembourg: Office of Official publications of the European Communities.

European Parliament. 2000. Lisbon European Council 23 and 24 March 2000. Presidency conclusions. http://www.europarl.europa.eu/summits/lis1 en.htm European Union. 2014. Study on the Effective Use of Early Childhood Education and Care in Preventing Early School Leaving. Luxembourg: Publications Office of the European Union. 
Foucault, M. 1975a. I, Pierre Riviere, having slaughtered my mother, my sister and my brother ... A case of parricide in the 19th century. Translated by F. Jellinek. New York: Random House, Pantheon Books.

Foucault, M. 1975b. The Birth of the Clinic. New York: Vintage.

Foucault, M. 1984. "Nietzsche, Genealogy, History." In The Foucault Reader, edited by Paul Rabinow, 76-100. London: Penguin.

Foucault, M. 1991a. Discipline and Punish. London: Penguin Books.

Foucault, M. 1991b. "Politics and the Study of Discourse." In The Foucault Effect: Studies in Governmentality, edited by G. Burchell, G., C. Gordon, C. and P. Miller, 53-72. Chicago: University of Chicago Press.

Foucault, M. 2000a. "Polemics, Politics, and Problematizations." In Michel Foucault: Ethics, edited by Paul Rabinow, 111-120. London: Penguin.

Foucault, M. 2000b. "On the Genealogy of Ethics." In Michel Foucault: Ethics, edited by Paul Rabinow, 253-80. London: Penguin.

Foucault, M. 2000c. "The Ethics of the Concern for Self as a Practice of Freedom." In Michel Foucault: Ethics, edited by Paul Rabinow, 281-301. London: Penguin.

Foucault, M. 2000d. "Technologies of the Self." Michel Foucault: Ethics, edited by Paul Rabinow, 223-251. London: Penguin.

Foucault, M. 2000e. "The Birth of Biopolitics." In Michel Foucault: Ethics, edited by Paul Rabinow, 73-80. London: Penguin.

Foucault, M. 2002a. "Truth and Juridical Forms." In Michel Foucault: Power, edited by James Faubion, 1-133. London: Penguin.

Foucault, M. 2002b. "Governmentality." In Michel Foucault: Power, edited by James Faubion, 201-222. London: Penguin.

Foucault, M. 2002c. The Archaeology of Knowledge. Translated by R. Sheridan. London: Routledge.

Foucault, M. 2008. The Birth of Biopolitics: Lectures at the Collège de France 1978-1979. Translated by Graham Burchell. Basingstoke: Palgrave Macmillan.

Grek, S., Lawn, M., Lingard, B. and Varjo, J. 2009. “North by Northwest: Quality Assurance and Evaluation Processes in European Education." Journal of Educational Policy 24 (2): 121-133. 
Hingel, A. 2001. Education policies and European governance. Brussels: European Commission - Directorate-General for Education and Culture.

Hodgson, D. 2011. "Policy Rationalities and Policy Technologies: a Programme for Analysing the Raised School-Leaving Age in Western Australia." Journal of Education Policy 26 (1): $115-130$.

Jäger, S. and Maier, F. 2009. "Theoretical and Methodological Aspects of Foucauldian Critical Discourse Analysis and Dispositive Analysis." In Methods of critical discourse analysis, 2nd ed., edited by Ruth Wodak and Michael Meyer, 34-61. London: Sage.

Janne, H. 1973. For a Community policy on education. Bulletin of the European Communities Supplement 10/73. http://aei.pitt.edu/mwginternal/de5fs23hu73ds/progress?id=JPUMQrwxQGs295-Wm7JL1PFWtQRsFH6t_tYURsx430,\&dl

Jones, H.C. 2005. "Lifelong Learning in the European Union: Whither the Lisbon Strategy?" European Journal of Education 40 (3): 247-260.

Lange, B. and Alexiadou, N. 2010. "Policy Learning and Governance of Education Policy in the EU." Journal of Education Policy 25 (4): 443-463.

Lawn, M., and Grek, S. 2012. Europeanizing Education: Governing a New Policy Space. Oxford: Symposium Books.

Nouwen, W., Clyq, N., and Uličná, D. 2015. Reducing the Risk that Youth with a Migrant Background will Leave School Early. Brussels: SIRIUS Network. http://www.siriusmigrationeducation.org/wp-content/uploads/2015/02/SIRIUS-EarlySchoolLeavingFINAL.pdf

Olssen, M. 2003. "Structuralism, Post-structuralism, Neo-liberalism: Assessing Foucault's Legacy." Journal of Education Policy 18 (2): 189-20.

Olssen, M. 2006. Michel Foucault: Materialism and Education. Boulder, CO: Paradigm Publishers.

Oomen, A., and Plant, P. 2014. Early School Leaving and Lifelong Guidance. Helsinki: European Lifelong Guidance Policy Network. http://www.elgpn.eu/publications/browse-by-language/english/elgpn-conceptnote-no.-6-early-school-leaving-and-lifelong-guidance/

Ozga, J. 2013. "Accountability as a Policy Technology: Accounting for Education Performance in Europe." International Review of Administrative Sciences 79 (2): 292-309. 
Pépin, L. 2011. Education in the Lisbon Strategy: Assessment and Prospects. European Journal of Education 46 (1): 25-35.

Reid, C. and Young, H. 2012. "The New Compulsory Schooling Age Policy in NSW, Australia: Ethnicity, Ability and Gender Considerations." Journal of Education Policy 27 (6): 795-814.

Ross, A. and Leathwood, C. 2013a. "Editorial: Conceptualising Early School Leaving." European Journal of Education 48 (3): 327-330.

Ross, A. \& Leathwood, C. 2013b. "Problematising Early School Leaving." European Journal of Education 48 (3): 405-418.

Schraad-Tischler, D., and Kroll, C. 2014. Social Justice in the EU - a Cross-national Comparison (SIM - Index Report). Gütersloh: Bertelsmann Stiftung. http://news.sginetwork.org/uploads/tx_amsgistudies/Social-Justice-in-the-EU-2014.pdf

Schultz, T. 1960. "Capital Formation by Education." The Journal of Political Economy 68 (6): 571-583.

Schultz, T. 1961. "Investment in Human Capital." The American Economic Review 51 (1): 117.

Schultz, T. 1962. "Reflections on Investment in Man." The Journal of Political Economy 70 (6): 1-8.

Sen, A. 2011. "Growth and other Concerns." The Hindu, February 14.

http://www.thehindu.com/opinion/op-ed/growth-and-otherconcerns/article1451973.ece

Souto-Otero, M., Fleckenstein, T. and Dacombe, R. 2008. "Filling in the Gaps: European Governance, the Open Method of Coordination and the European Commission." Journal of Education Policy 23 (3): 231-249.

Vajello, C. and Dooly, M. 201). "Early School Leavers and Social Disadvantage in Spain: from Books to Bricks and Vice-versa." European Journal of Education 48 (3): 390-404.

van Dijk, T. 2009. "Critical Discourse Studies: a Sociocognitive Approach." In Methods of critical discourse analysis, 2nd ed., edited by Ruth Wodak and Michael Meyer, 62 86. London: Sage.

Word count: 8361

Author details: 
Donald Gillies, University of the West of Scotland* donald.gillies@uws.ac.uk

Denise Mifsud, University of the West of Scotland denise.mifsud@uws.ac.uk

*corresponding author 